\title{
THE VECTOR OF TRANSFORMATION OF THE MODEL OF THE AUDITING OF PUBLIC INTEREST ENTERPRISES IN UKRAINE
}

\author{
Dmytrenko I. N. \\ Doctor of Economics, Associate Professor, Professor of the National Center for Accounting and \\ Auditing of the National Academy of Statistics, Accounting and Auditing, Ukraine \\ irynadmytrenk01308@gmail.com
}

\begin{abstract}
The subject of this publication is to substantiate the vector of transformation of the traditional audit model for public interest enterprises in Ukraine, taking into account the synergy of qualitative characteristics of the evolution of audit in world practice, the specifics of the establishment of an audit institute in Ukraine, the need to synthesize a system-oriented and risk-oriented audit methodology. An integrated audit model has been substantiated and proposed with the expansion of the subject area for evaluating systems that generate information not only about the state and results of public interest enterprises, but also about their ability to ensure business continuity, value increment and sustainable development for the future under conditions of uncertainty. The advantages of using an integrated model in the practice of auditing public interest enterprises are demonstrated, which are associated with a substantial minimization of the gap between the expectations of stakeholders and the results of the audit, as well as information risks when making economic (in particular, investment) decisions.

The purpose of the study was to substantiate the relevance, nature and elements of an integrated model of the auditing of public interest enterprises as the main goal of transformational transformations by identifying the methodological features of audit steps in world practice, identifying and systematizing the signs of an institutionalized audit in Ukraine, establishing the specificity of the expanded subject area and the audit procedures.

Sources and research methods: The information base of the study was the International Standards for Quality Control, Audit, Review, Other Provision of Confidence and Related Services (2016-2017) of the Council on International Standards on Auditing and Providing Confidence of the International Federation of Accountants; Model COSO ERM (2004, 2013, 2017); International Integrated Reporting Standard; EU Directives 2006/43/EU, 2013/34/EU, 2014/56/EU and Regulation (EU) 537/2014 regarding the regulation of the audit of financial statements of public interest enterprises; official statistics on the development of audit activities in Ukraine; scientific publications; personal observations of the author.

The study used methods of analogy and synthesis; systematic approach and systematization; dialectical, historical, logical, hypothetical-deductive, economic-statistical methods.

Results and practical importance: the obtained results allow us to conclude that the traditional model of auditing is ineffective for enterprises of public interest in Ukraine; the consistency of the synthesis of the methodology of systemic and risk-based auditing in an integrated audit model for such enterprises, which provides qualitative transformations to eliminate gaps in the development and development of the audit institute in Ukraine. At the same time, the results of the study are interesting from the point of view of the formation of modern ideas about how to minimize the gap of expectations of stakeholders in the practice of auditing public interest enterprises.

Keywords: institute of audit, public interest enterprises, integrated audit model, gap of stakeholder expectations, business continuity, sustainable development.
\end{abstract}




\section{INTRODUCTION}

The vector of development of audit as an element of a market infrastructure that is able to protect interests and meet the information needs of a society determines the current realities of the socio-economic space of Ukraine. These realities are characterized by deepening of globalization processes, integration into the world economic community, strengthening of the influence of corporate sector companies of public interest on the formation of gross domestic product. According to the Global Rating 500, about $80 \%$ of GDP in developed countries and almost $30 \%$ in developing countries are produced by business entities of this form of organization [11]. As a result, the requirements for transparency of reporting companies of public interest and the completeness of the implementation of the public mission of mandatory audit are increased, as a result of the expansion of the range of information requests of users under uncertainty. These requirements are enshrined in the EU Directives 2006/43 / EC [4], 2013/34 / EC [5], 2014/56 / EC [6] and Regulation (EC) $537 / 2014$ [16]. However, there is a relatively slow implementation of the EU requirements in the Ukrainian legislation on the regulation of audit activities [22], the theory and practice of compulsory audit of business entities of public interest from the modern requirements is lagging behind.

Therefore, further research needs the exact problems of the theory and methodology of audit, the solution of which will reduce the "gap of expectations" of users, improve the quality of independent audit and ensure that society recognizes its necessity. The problem remains the discrepancy between the subject of mandatory audit of public interest enterprises (PIE) and the information expectations of users; the lack of an audit methodology for those information generation systems that provide an understanding of the degree of manageability of future development risks and the continuity of companies. The decisive factor in the impact of the new vision of PIE audit scope is the current content of user expectations for information on the sensitivity of these companies to future risk events and to ensure continuity of operations. Therefore, today's request is the substantiation and complex development of the integrated model of PIE audit as the basis for transformational transformations, taking into account the evolution of audit in world practice, systematization of the signs of institutionalization of audit in Ukraine, the establishment of the specifics of the extended domain and procedures of the new format.

\section{SOURCES AND METHODS}

The study used methods of analogy and synthesis; systematic approach and systematization; dialectical, historical, logical, hypothetical-deductive, economic-statistical methods.

Dialectical, historical and logical methods are used to distinguish the signs of institutionalization of audit in Ukraine and to study the modification of the methodological principles of audit at the stages of its evolution.

Formation and gradual development of institutions and institutional environment is becoming the most important factor in the sustainable functioning of economic systems and society as a whole. In particular, this relates to the Institute of Independent Professional Audit and the increased need for its effective functioning in the most risky environment of public interest enterprises.

Today, in different flows of institutionalism, several definitions of the term "institute" with a rather diverse interpretation are proposed [12], [15], [16], [18], [19], [23], [24]. However, in them, the related basis of the essence of the notion of "institute" is the order established in society in the form of the corresponding "rules of the game", norms, laws or guidelines. The main measure of the institutional design of a particular phenomenon in a society should be considered the immanence of such institutional features: sociopsychological, sociological, legal, and economic. The degree of immanence of the audit in Ukraine of the indicated institutional features on the basis of an analysis of the nature of their manifestation is presented in Table 1.

The study points to the process of obtaining a certain institutional form of obtaining independent audit in Ukraine. This is confirmed by the presence of: institutional features with a specific peculiarity of their manifestation; appropriate frameworks of existence (formal, informal, spontaneous); the dynamics of the functioning of auditors in the market of audit services and in the surrounding institutional environment (property, power, corporate governance, labor).

In the corporate governance environment, the riskiness of activities of public interest entities under the influence of business diversification, the existence of corporate conflicts of interest, and the inability of management to constantly take into account the interests of all groups of owners, in particular minority shareholders, is significantly increasing.

As a result, the institutional design of domestic audits, especially those of public interest enterprises, lags behind the general manifestation of institutional features, in particular: socio-psychological (users' 
expectations are not justified because of the limited scope of the mandatory audit); legal (there are no legislative requirements for ensuring the extension of the scope of mandatory audit); sociological (insufficient protection of interests of minority shareholders and potential investors). This exacerbates the problem of "gap of expectations" from the results of compulsory audit and updates the need for its solution by transforming the model of audit of public interest enterprises and introducing legislative initiatives to protect the interests of users.

Table 1. Institutional attributes and their immanence for professional audit in Ukraine

\begin{tabular}{|l|l|}
\hline $\begin{array}{c}\text { Institutional } \\
\text { features }\end{array}$ & \multicolumn{1}{c|}{$\begin{array}{c}\text { The nature of the manifestation of signs about } \\
\text { professional audit }\end{array}$} \\
\hline $\begin{array}{l}\text { Socio- } \\
\text { psychological }\end{array}$ & $\begin{array}{l}\text { Evolution of the audit (from the point of view of professional behavior and the } \\
\text { formation of more advanced theoretical-methodological and organizational principles } \\
\text { of professional activity) under the influence of changes in the socio-cultural } \\
\text { environment and user expectations }\end{array}$ \\
\hline Sociological & $\begin{array}{l}\text { The public recognition of audits as a tool for market infrastructure and professional } \\
\text { activities aimed at protecting economic interests and meeting the information needs } \\
\text { of society, in particular users of financial reporting and other non-financial information } \\
\text { of public interest enterprises }\end{array}$ \\
\hline Legal & $\begin{array}{l}\text { The consolidation of the legal basis of the audit in the Law of Ukraine "On Audit of } \\
\text { Financial Reporting and Auditing" and in other normative acts on the mandatory audit } \\
\text { of public interest enterprises }\end{array}$ \\
\hline Economic & $\begin{array}{l}\text { Recognition of an audit by an exclusive type of business with the corresponding } \\
\text { receipt of specific income for the provision of intellectual services, consisting both in } \\
\text { expressing an independent opinion and ensuring the user's confidence in the } \\
\text { reporting company information, and in the implementation of accompanying services, } \\
\text { where assurance is not provided }\end{array}$ \\
\hline
\end{tabular}

Source: compiled by the author

Economic and statistical methods were used to establish trends in the audit of public interest enterprises in Ukraine. Thus, the data in Table 2 clearly confirms the implementation of the phenomenon of "gap of expectations" in the Ukrainian audit.

Table 2. The ratio of the average cost of tasks with mandatory and initiative audit of financial statements of public interest enterprises for 2009-2017

\begin{tabular}{|c|c|c|c|}
\hline \multirow{2}{*}{ Years } & \multicolumn{2}{|c|}{ Average cost of one order, ths. UAH } & Coefficient \\
\cline { 2 - 3 } & $\begin{array}{c}\text { Mandatory audit of } \\
\text { financial statements }\end{array}$ & $\begin{array}{c}\text { Initiative audit of } \\
\text { financial statements }\end{array}$ & $\mathbf{7 , 9 6}$ \\
\hline $\mathbf{2 0 0 9}$ & 9,56 & 76,07 & $\mathbf{1 2 , 8 3}$ \\
\hline $\mathbf{2 0 1 0}$ & 9,01 & 115,64 & $\mathbf{8 , 3 9}$ \\
\hline $\mathbf{2 0 1 1}$ & 15,58 & 130,82 & $\mathbf{8 , 8 9}$ \\
\hline $\mathbf{2 0 1 2}$ & 16,51 & 146,85 & $\mathbf{7 , 3 7}$ \\
\hline $\mathbf{2 0 1 3}$ & 20,13 & 148,46 & $\mathbf{5 , 9 5}$ \\
\hline $\mathbf{2 0 1 4}$ & 25,83 & 153,59 & $\mathbf{7 , 7 6}$ \\
\hline $\mathbf{2 0 1 5}$ & 29,53 & 229,19 & $\mathbf{6 , 6 3}$ \\
\hline $\mathbf{2 0 1 6}$ & 38,07 & 252,57 & $\mathbf{5 , 9 7}$ \\
\hline $\mathbf{2 0 1 7}$ & 46,77 & 279,06 & \\
\hline
\end{tabular}

Source: compiled by the author on the basis of [10]

The "gap of expectations" in the audit is the discrepancy between audit user requests and the results that auditors provide after completing certain tasks.

Therefore, our research has identified a preponderance of interest in ordering the tasks of the initiative audit, 
which is confirmed by an increase in the average cost of such tasks compared with the mandatory audit, approximately 8 times for each of the last nine years (2009-2017). That is, the current format of compulsory audit is not able to provide the expected level of satisfaction of the information needs of users of financial reporting of enterprises of public interest.

However, public recognition of the audit profession is not possible without reducing the "gap of expectations" by providing users with confidence in a wider range of relevant information. And this leads to the search for a vector of transformation of the audit model of enterprises of public interest.

Risk of integration processes in the corporate sector of Ukraine causes new information requests of potential participants (primarily investors) to gain assurance about the real ability of a company as an $M$ \& $A$ entity to implement strategic goals based on the available financial potential. Consequently, in view of the increasing negative globalization trends and the need to reduce the information risk of users of corporate systems reporting, the role and demand for independent auditing as an institution in the community should increase. That is why the need for auditing a new qualitative level is intensified, where the expression of independent professional opinion will be based on obtaining and providing sufficient confidence to users (especially informally unprotected, minority shareholders, potential investors) not only about the status and achieved results of the activities of the said companies, as well as their the future.

The logical analysis of the evolution of theoretical foundations and audit practice has allowed us to establish that the development of approaches to the collection of audit evidence and the reasoning of the independent opinion of the auditors was influenced by the expansion of the information needs of users of financial reporting companies before making managerial decisions based on the assurance of its reliability. In particular, it was found that at the stage of the confirmatory audit (the end of the nineteenth century - the 30th years of the XX century), the concept of "independent thought" as a result of professional activity of specialists has not yet been formed, and therefore the receipt of audit evidence was carried out mainly with the use of mandatory continuous verification to identify the "audit trail".

The initial understanding of the essence of the system-oriented audit (40th - 80th years XX century) focused on assessing the state of the internal control system only in view of its ability to ensure the accuracy of the information in the accounting and financial reporting of the client companies (Table 3). With the active phase of development of this stage in the world, the process of international standardization of audit activity began, which pushed the audit to the next stage - risk-oriented.

Table 3. Semantic features of the initial perception of system-oriented audit in the context of the evolution of theory and practice

\begin{tabular}{|c|c|c|}
\hline $\begin{array}{l}\text { Basic } \\
\text { the theory }\end{array}$ & $\begin{array}{l}\text { Conceptual } \\
\text { platforms }\end{array}$ & Realization in practice of audit \\
\hline \multirow[t]{2}{*}{$\begin{array}{l}\text { The } \\
\text { theory of } \\
\text { agents } \\
\text { the theory } \\
\text { of "dogs - } \\
\text { nipples" }\end{array}$} & $\begin{array}{l}\text { The concept of R. Montgomery } \\
\text { The initial idea is recognition that the } \\
\text { interests of users of financial reporting } \\
\text { are not only diverse, but also contain } \\
\text { certain contradictions, because they } \\
\text { are associated with the adoption of } \\
\text { multidirectional decisions. An audit } \\
\text { should be performed not for the sake } \\
\text { of abstract truth, but for the benefit of } \\
\text { different groups of users } \\
\text { The purpose of the audit is to } \\
\text { identify and clarify the actual financial } \\
\text { conditions and level of incomes of the } \\
\text { client enterprise in the interests of its } \\
\text { owners, bankers, investors and other } \\
\text { users of financial reporting. }\end{array}$ & $\begin{array}{l}\text { application of selective testing from the point of view } \\
\text { of the fact that there is no need for absolutely } \\
\text { accurate data, and the level of their accuracy should } \\
\text { be adequate to the general tendencies of enterprise } \\
\text { development; } \\
\text { application of the relationship between the objectives } \\
\text { that the customer has set before the auditor and the } \\
\text { approaches to performing the task (collection of audit } \\
\text { evidence); } \\
\text { recognition of the need for an auditor to test the } \\
\text { effectiveness of an internal control system (conformity } \\
\text { tests) formed at the enterprise prior to } \\
\text { commencement of work and in case of a positive } \\
\text { result of the decision to reduce the amount of detailed } \\
\text { testing in substance; } \\
\text { Independent opinion of the auditor becomes the } \\
\text { result of (informational product) of audit work }\end{array}$ \\
\hline & $\begin{array}{l}\text { The concept of R. Adams } \\
\text { The original idea - the system of } \\
\text { internal control is recognized as the } \\
\text { object of special attention of auditors, } \\
\text { because in the conditions of its } \\
\text { effective functioning the probability of } \\
\text { accidental mistakes (or fraud) in the } \\
\text { accounting and financial reporting is }\end{array}$ & $\begin{array}{l}\text { - achieving the goal of the audit involves evaluating the } \\
\text { systems of internal control of clients and establishing } \\
\text { the state of functioning of these systems; } \\
\text { - internal control system is considered as a means of } \\
\text { detecting errors, preventing abuse and ensuring the } \\
\text { completeness of accounts at the level of the } \\
\text { enterprise-client; }\end{array}$ \\
\hline
\end{tabular}




\begin{tabular}{|c|c|c|}
\hline & $\begin{array}{l}\text { insignificant } \\
\text { The purpose of the audit is to } \\
\text { express an opinion on the truthfulness } \\
\text { and objectivity of the published } \\
\text { financial statements and thus to } \\
\text { strengthen user confidence. } \\
\text { Standardization of audit - is the } \\
\text { beginning of the international } \\
\text { standardization of audit activity }\end{array}$ & $\begin{array}{l}\text { system of internal control is used in determining the } \\
\text { nature, volume and duration of audit procedures for } \\
\text { obtaining audit evidence; } \\
\text { establishment of fidelity and objectivity of financial } \\
\text { reporting takes place on the basis of information } \\
\text { obtained on the results of testing of the internal } \\
\text { control system of the enterprise-client; } \\
\text { the mandatory element of the audit report is to } \\
\text { express an opinion as to the reliability of the audited } \\
\text { financial statements and compliance with the client's } \\
\text { generally accepted accounting principles (for audit } \\
\text { tasks - expressing confidence in a positive form) }\end{array}$ \\
\hline
\end{tabular}

Source: compiled by the author on the basis of [1], [2], [9], [17], [21]

The initial perception of the essence of risk-based audit (90th years of XX century - the beginning of the XXI century) focused only on identifying the probability of material misstatement of financial reporting and determining the impact of the risk of inefficiency of internal control at the level necessary for planning an audit task (Table 4).

Table 4. Semantic features of the initial perception of risk-based audit in the context of the evolution of theory and practice

\begin{tabular}{|c|c|c|}
\hline $\begin{array}{l}\text { Basic } \\
\text { the theory }\end{array}$ & $\begin{array}{l}\text { Conceptual } \\
\text { platforms }\end{array}$ & Realization in practice of audit \\
\hline \multirow[t]{2}{*}{$\begin{array}{l}\text { The theory } \\
\text { of agents } \\
\text { the theory } \\
\text { of } \\
\text { consulting } \\
\text { theory of } \\
\text { "dog- } \\
\text { guide" }\end{array}$} & $\begin{array}{l}\text { The concept of R. Adams } \\
\text { The starting point is the targeting } \\
\text { of auditors to selective research } \\
\text { mainly in those areas of financial } \\
\text { and economic activity, where the } \\
\text { risk of distortions and fraud is } \\
\text { maximal } \\
\text { The purpose of the audit is to } \\
\text { express an opinion not only on the } \\
\text { reliability of financial statements, } \\
\text { but also on the effectiveness of the } \\
\text { enterprise }\end{array}$ & $\begin{array}{l}\text { - obtaining audit evidence not only from the study of } \\
\text { internal control systems, but also from conducting } \\
\text { procedures for analyzing and taking into account the } \\
\text { factors of internal risk of enterprises - clients; } \\
\text { - the nature, scope, duration of the sampling testing } \\
\text { procedures is essentially determined by the risk } \\
\text { assessment of the individual components: the inherent } \\
\text { risk, the risk of inefficiency of the internal control } \\
\text { system, the risk of non-disclosure; } \\
\text { application of analytical procedures for obtaining } \\
\text { evidence of weaknesses in the management of the } \\
\text { enterprise and expressing an opinion on the efficiency } \\
\text { of the enterprise }\end{array}$ \\
\hline & $\begin{array}{l}\text { The concept of J. Robertson } \\
\text { The initial idea is to target auditors } \\
\text { to reduce the risk of inaccurate (or } \\
\text { distorted) disclosure in financial } \\
\text { statements published by companies } \\
\text { The purpose of the audit is to } \\
\text { reduce to an acceptable level of } \\
\text { information risk for users of } \\
\text { financial statements }\end{array}$ & $\begin{array}{l}\text { - the application of professional skepticism to all material } \\
\text { facts, which is reflected by the managerial staff in the } \\
\text { accounts and reporting; } \\
\text { sufficient information on the state of internal control is } \\
\text { recognized as the basis for planning the nature, scope } \\
\text { and scale of the required sample testing; } \\
\text { - } \text { the results of the internal control system evaluation are } \\
\text { used to indicate the degree of manageability and } \\
\text { business risk constraints of the enterprise-client; } \\
\text { application of verification during the collection of audit } \\
\text { evidence as an opportunity to obtain data on any issue } \\
\text { and its evaluation by an acceptable criterion and } \\
\text { established level of materiality; } \\
\text { the basis for evaluating the financial statements is the } \\
\text { substantial and sufficient information obtained during } \\
\text { the inspections, observations, surveys and } \\
\text { confirmations; } \\
\text { an important factor in expressing an opinion of the } \\
\text { auditor is the degree of compliance of the enterprise- } \\
\text { client with the assumption of continuity of activity; } \\
\text { establishing professional accountability of auditors for } \\
\text { the validity of opinions not only to clients, but also to } \\
\text { third parties }\end{array}$ \\
\hline
\end{tabular}

Source: compiled by the author on the basis of [1], [2], [9], [17], [21]

The risk-based audit phase initiated the use of professional skepticism, where the criterion for evaluating detected distortions is the level of materiality. The auditor's independent opinion is already influenced not 
only by the presence of significant distortions in the financial statements of the client company, but also by adhering to the assumption of the continuity of its activities.

It should be noted that the current state of independent audit in Ukraine indicates its predominant affiliation with the confirmatory stage of development with the existing features of capacity and the need to move to the next levels of evolution. In addition, significant business risks that accompany the operation of public interest entities increase the need for obtaining additional confidence from stakeholders for the prospects of the activity for making strategic investment decisions. This includes ensuring managed riskiness, stability and continuity of companies' economic activity, and their ability to create value.

The current stage of the Ukrainian audit development is characterized by the need to develop a new model that involves the integration of theoretical and methodological foundations as a system-oriented and riskbased audit, which will ensure reduction of information risks of stakeholders to make sound management decisions. Under these conditions, a professional external audit should focus on evaluating and expressing an independent view of the extended composition of objects and their subject area. This applies not only to information on the economic events that have taken place and to the accounting-generalization. Particular attention is already needed for information on the sustainability of the future development of companies.

The use of hypothetical-deductive and analogue and synthesis methods has given an opportunity to substantiate the directions of widening the subject area of the audit regarding the results and prospects of the PIE. A systematic approach and systematization contributed to the identification and synthesis of elements of the PIE integrated audit model.

\section{RESULTS}

It is proved that in order to reduce the level of "gap of expectations", objects of audit of the reporting information of enterprises of public interest should include a set of systems for generating information flows about the status, results and prospects of their activities, taking into account the impact of the risks of inefficiency of functioning on the future development of these companies.

We believe that in order to ensure public recognition and fulfillment of its mission in society, the subjects of audit activity should reorient the practice of providing assurance to service customers and other users (especially those for whom the auditor's report is the only source of understanding of the actual state of affairs of companies - minority shareholders and potential investors) for such a complex system of objects:

1) the system of business processes;

2) the system of accounting and reporting;

3) the system of internal corporate control;

4) the system of management of business risk;

5) the system of corporate governance.

These system objects are typified by the nature of their influence on the professional judgment of the auditor regarding: the actual state at the reporting date (objects of retrospective value); prospects for the development of client companies (objects of perspective value), ensuring the proper level of functioning (objects of warning and corrective value).

The risk-oriented audit of the quality of the operation of system objects of retrospective value will not only allow the establishment of material misstatements in the financial statements and provide assurance about the degree of its reliability. It will also help identify the risk of such distortions, starting with the level of business processes, and taking into account the impact of this risk on the state of accounting and generalization by identifying the probability of fraud by linear management and the relevant personnel of the client companies. The implementation of a risk-oriented audit of systemic objects of perspective value will enable the degree of manageability of events of significant uncertainty, compliance with their acceptable level of risk-appetite of client companies and the impact on ensuring the continuity of their activities.

The methodological principles of risk-based auditing as one of the components of an integrated model of audit of public interest entities in a practical plane should also be implemented in the light of the assessment by independent auditors of the extent to which the COSO ERM [3], [4], [5] requirements for the design and operation of all systems information generation, and especially internal control system.

The system of internal corporate control is a special object of an auditor's assessment because, in the conditions of adequate organization and proper implementation, this system has a preventive and corrective character regarding the proper functioning of other system objects, and therefore can affect their quality status. The subject of the audit of the system of internal corporate control is its ability to alert, detect and 
timely correct certain deviations from the reference state of other system objects.

Therefore, in the definition of the author, an integrated model of auditing of public interest enterprises is a form of external independent audit that combines the theoretical and methodological principles of systemoriented and risk-based audit and ensures users' confidence in the reliability of reporting information about the status, results and prospects for future development of these companies, based on the determination of the acceptability of the level of residual business risks to ensure the sustainability, continuity of their activities (Figure 1).

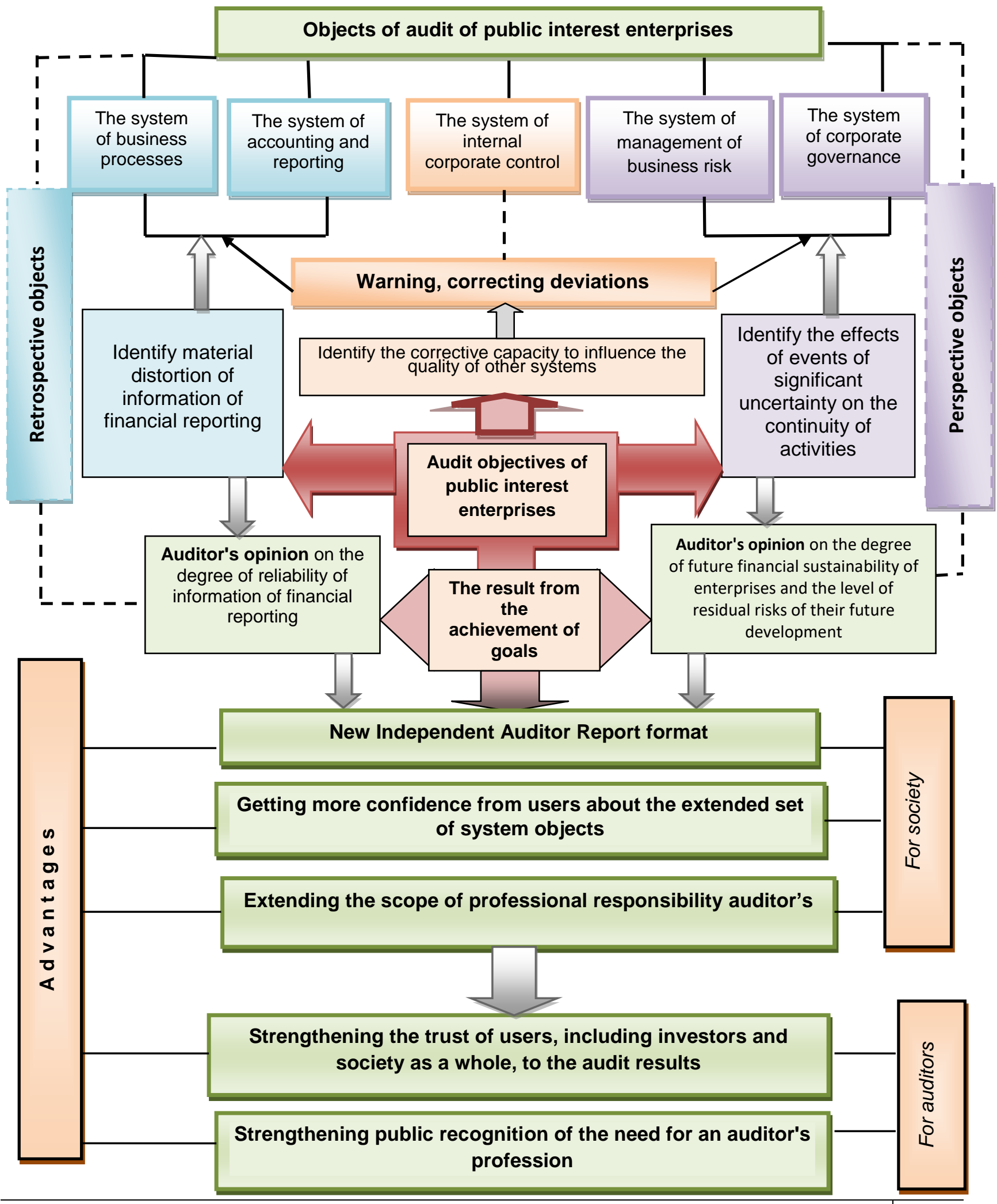




\section{Fig. 1. Formalized presentation of an integrated model of audit of enterprises of public interest}

\section{Source: compiled by the author}

The reporting information in the context of the proposed definition should be understood as the information of the financial statements and other non-financial information provided and officially published by the companies of the public interest. In particular, it is a complete set of integrated reporting, in accordance with the International Standard for Integrated Reporting [13], and is an important source of information for auditing the proposed set of system objects.

The duality of the essence of the integrated model of audit of enterprises of public interest manifests itself in the fact that, firstly, the auditor's actions are aimed at establishing the availability and functioning of the complex of system objects, and secondly, it is the basis for the further application of risk-oriented means audit to these objects (Table 5). In turn, the definition of the level of risks of inefficiency of system objects affects the justification of the professional judgment of the auditor and transformation of it into professional opinion on the basis of the evidence base. As a result, the integrated application of the principles of systemoriented and risk-oriented audit to a complex of objects is the basis for expanding the limits of expressing the professional opinion of the auditor in the direction of prospects for the development of enterprises of public interest.

Table 5. Comparative characteristic of the essence system-oriented and risk-based audit and an integrated model of audit of public interest enterprises

\begin{tabular}{|c|c|c|c|}
\hline $\begin{array}{l}\text { Elements of } \\
\text { the essence }\end{array}$ & System-oriented audit & Risk-based audit & $\begin{array}{l}\text { Integrated model of audit of public } \\
\text { interest enterprises }\end{array}$ \\
\hline Initial idea & $\begin{array}{l}\text { The audit should be } \\
\text { carried out in the interests } \\
\text { of different groups of } \\
\text { users, who take } \\
\text { multidirectional decisions }\end{array}$ & $\begin{array}{l}\text { Audit orientation on sample } \\
\text { surveys are those areas of } \\
\text { economic activity that are } \\
\text { vulnerable to business risks, } \\
\text { and where the likelihood of } \\
\text { distortions in accounting and } \\
\text { reporting and fraud is highest }\end{array}$ & $\begin{array}{l}\text { Integration of theoretical and } \\
\text { methodological foundations of } \\
\text { system-oriented and risk-oriented } \\
\text { audit and application of their methods } \\
\text { to an expanded subject area - } \\
\text { subsystems of information generation } \\
\text { - taking into account the impact of the } \\
\text { risks of their inefficiency on the } \\
\text { sustainability of future development of } \\
\text { public interest enterprises }\end{array}$ \\
\hline Goal & $\begin{array}{l}\text { Expressing an opinion on } \\
\text { the degree of reliability of } \\
\text { financial statements that is } \\
\text { published, providing } \\
\text { assurance to users about } \\
\text { the relevance of its } \\
\text { information }\end{array}$ & $\begin{array}{l}\text { Expressing opinions is not } \\
\text { only about the degree of } \\
\text { reliability of financial } \\
\text { statements, as well as on the } \\
\text { effectiveness of the } \\
\text { company-client; reducing the } \\
\text { information risk of users to an } \\
\text { acceptable level }\end{array}$ & $\begin{array}{l}\text { Expressing opinions not only about } \\
\text { the status, results, as well as about } \\
\text { the prospects, manageable residual } \\
\text { risks and the sustainability of the } \\
\text { future development of corporate } \\
\text { systems; reducing the "gap of } \\
\text { expectations" of stakeholder }\end{array}$ \\
\hline Object & $\begin{array}{l}\text { Information of accounting } \\
\text { and financial reporting }\end{array}$ & $\begin{array}{l}\text { Information of accounting } \\
\text { and financial reporting }\end{array}$ & $\begin{array}{l}\text { Financial Reporting Information and } \\
\text { Non-Financial Information in the } \\
\text { Integrated Reporting format } \\
\text { (according to the IIRC) }\end{array}$ \\
\hline Subject & $\begin{array}{l}\text { The state of the internal } \\
\text { control system of the client } \\
\text { company as a guarantor of } \\
\text { the quality of the } \\
\text { accounting and financial } \\
\text { reporting system }\end{array}$ & $\begin{array}{l}\text { The state of the internal } \\
\text { control system of the client } \\
\text { company, taking into account } \\
\text { its ability to prevent the } \\
\text { negative impact of fraud risk } \\
\text { and distortion of financial } \\
\text { reporting information. }\end{array}$ & $\begin{array}{l}\text { Quality of systems for generating } \\
\text { information about the status, results } \\
\text { and prospects of the client company } \\
\text { (business process system, accounting } \\
\text { and reporting system, internal control } \\
\text { system, business risk management } \\
\text { system, corporate governance } \\
\text { system) }\end{array}$ \\
\hline & \multicolumn{3}{|c|}{ External Independent Audit Form which provides assurance to users about: } \\
\hline
\end{tabular}




\begin{tabular}{|l|l|l|l|}
\hline Definition & $\begin{array}{l}\text { the reliability of the } \\
\text { financial statements of the } \\
\text { client company on the } \\
\text { basis of determining the } \\
\text { state of its internal control } \\
\text { system }\end{array}$ & $\begin{array}{l}\text { the reliability of financial } \\
\text { reporting and the } \\
\text { effectiveness of the } \\
\text { economic activity of the client } \\
\text { company on the basis of } \\
\text { determining the ability of its } \\
\text { internal control system to } \\
\text { maintain this activity within } \\
\text { the limits of permissible risk } \\
\text { appetite }\end{array}$ & $\begin{array}{l}\text { the reliability of reporting information } \\
\text { (integrated reporting) on the status, } \\
\text { outcomes and prospects for the future } \\
\text { development of companies that are } \\
\text { corporate systems, based on } \\
\text { determining the acceptability of the } \\
\text { level of residual business risks to } \\
\text { ensure the sustainability, continuity of } \\
\text { their activities }\end{array}$ \\
\hline
\end{tabular}

Source: compiled by the author

For the successful completion of appropriate audit procedures for assessing the state of the system objects of the extended subject area in the contour of the proposed integrated model of audit of enterprises of public interest, such procedures should be unified and approved at the level of the complex of internal standards.

Thus, the pragmatic value of an integrated model of audit of public interest enterprises is to realize the ability to substantially increase the degree of confidence in the full range of system objects that correspond to the current content of the expectations of different groups of stakeholders (especially the most informally unprotected - minority shareholders and potential investors) in terms of adoption management decisions and reducing the risk of corporate conflicts of interest.

This is embodied in the proposed format of the Independent Auditor's Report and helps to reduce the "gap of expectations" of the stakeholders from the audit results. Thus, the new format of the Independent Auditor's Report, in addition to meeting the standardized requirements of ISA 700 "Formation of Opinion and Reporting on Financial Statements" [14], should cover the results of the procedures performed and the final opinion on:

1) the quality of the business process system and its impact on the company's ability to create value;

2) the adequacy of the information displayed in the accounting and reporting system, applied conceptually;

3 ) the degree of manageability of business risks and the impact of residual risks on the continuity of the company;

4) the quality of the corporate governance system and its impact on the interests of different groups of owners;

5) the degree of reliability of the system of internal corporate control to ensure the quality of functioning of the above-mentioned systems of information generation.

The introduction of the proposed format of the audit report contributes to a significant increase in the reasonableness of the auditor's professional judgment, the degree of confidence of the stakeholders, and the quality of the independent audit.

\section{CONCLUSIONS}

The institutional design of the Ukrainian audit in the environment of enterprises of public interest lags behind the general manifestation of institutional features. This exacerbates the problem of increasing the "gap of expectations" from the results of the mandatory audit and updates the need for its solution by modifying the theoretical, methodological and organizational principles of audit to ensure the protection of users' interests.

The current content of information expectations of stakeholders from the results of the mandatory audit of public interest enterprises is linked to the information community, which provides the need for additional confidence in the nature of the effects of the impact of risk events on the prospects for the development of such companies. This allowed to substantiate the directions of expansion of the subject area of mandatory audit of enterprises of public interest, primarily in terms of continuity of activities, the effectiveness of corporate management, internal corporate control, risk management.

The vector of transformation of traditional principles of compulsory audit to the integrated model of audit of enterprises of public interest is determined. The essence of this model is to combine and jointly apply theoretical and methodological foundations as a system-oriented and risk-based audit. Under these conditions, professional audit should focus on assessing and expressing an independent opinion on the 
extended composition of objects covering the full range of information flow generation systems in the public interest entities, taking into account the impact of the inefficiencies or inadequate functioning of the said system objects on the future development of such companies.

Thus, the practical implementation of the proposed integrated model of audit of enterprises of public interest will increase confidence in professional audit in Ukraine by both key users (owners and investors) and society as a whole, which forms the foundation for recognizing the need for the profession of auditor in the community.

\section{REFERENCE LIST}

Adams R. (1995). Osnovyi audita [Fundamentals of Audit]. Moscow : Audit, YuNITI, 398 pages.

Audit Montgomery (1997). [Montgomery Audit]. Moscow: Audit, YuNITI, 542 pages.

COSO ERM (2004). Enterprise Risk Management - Integrated Framework. Retrieved from http://www.coso.org.

COSO ERM (2013). Internal Control - Integrated Framework Executive Summary. Retrieved from http://www.coso.org.

COSO ERM (2017). Enterprise Risk Management - Integrating with Strategy and Performance. Retrieved from http://www.coso.org.

Directive 2006/43/EC of the European Parliament and of the Council of 17 May 2006 on the mandatory audit of annual reports and consolidated reports (2006). Retrieved from http:// www.zakon1.rada.gov.ua [in Ukrainian].

Directive 2013/34/EC of the European Parliament and of the Council of 26 June 2013. "On Annual Financial Statements, Consolidated Financial Statements and Associated Reports of Certain Types of Companies", amending the Directive 2006/43 / EC of the European Parliament and of the Council and repealing Directives 78/660/EEC and 83/349/EEC (2013). Retrieved from http://www.zakon1.rada.gov.ua [in Ukrainian].

Directive 2014/56/EC of the European Parliament and of the Council of 16 April 2014 amending Directive 2006/43/EC on statutory audit of annual accounts and consolidated accounts (concerning the European Economic Area) (2014). Retrieved from http:// www.apu.com.ua [in Ukrainian].

Dodzh R. (1992). Kratkoe rukovodstvo po standartam i normam audita [Quick Guide to Standards and Audit Standards]. Moscow: Finansyi i statistika, YuNITI, 240 pages.

Generalized information on the state of audit activity in Ukraine for 2009-2017. Retrieved from http:// www.apu.com.ua [in Ukrainian].

Global 500 2017: Fortune on CNNVMoney.com. Retrieved from http:// www.money.cnn.com/magazines/fortune/global500/2017/full_list.

Hodzhson Dzh.(2000). Privyichki, pravila i ekonomicheskoe povedenie [Habits, rules and economic behavior]. Voprosyi ekonomiki [Economic issues]. vol. 1, pp. 39-55.

International Council on Integrated Reporting (IIRC) standard (2008). Retrieved from http://www.integratedreporting.org/wp-content/uploads/2015/03/13-12-08 - The International -IrFramework.docx_en-US_ru-RU.pdf.

International Standards for Quality Control, Audit, Review, Other Provision of Confidence and Related Services of the Council on International Standards on Auditing and Providing Confidence of the International Federation of Accountants (2016-2017). Retrieved from http://www.ifac.org

Karagod V.S., Golubeva N.A., Erokhina E.I. (2017). Institute of Audit in Russia: Challenges and perspectives. Journal of Advanced Research in Law and Economics, vol. 8 (1), pp. 330-339.

Lafta D. (1999). Effektivnost menedzhmenta organizatsiy [Organizational management effectiveness]. Moscow: Myisl, pages.

Montgomery R.H. (1927). Auditing Theory and Practice. Fourth Edition. Revised and Enlarged. N.Y. The Ronald Press Company. 
Nort D. (1997). Institutyi, institutsionalnyie izmeneniya i funktsionirovanie ekonomiki [Institutions, institutional changes and the functioning of the economy]. Moscow: Fond ekonomicheskoy knigi «Nachala», 180 pages.

Pankov V.V. (2011). Institutsionalnaya teoriya buhgalterskogo ucheta i audita [Institutional Theory of Accounting and Auditing]. Moscow: «InformByuro», 168 pages.

Regulation (EC) 537/2014 of the European Parliament and of the Council of 16 April 2014. "On Special Requirements for Mandatory Audit of Subjects of Public Interest and Cancellation of Decision of the European Commission 2005/909/EC" (2014). Retrieved from http://www.eur-lex.europa.eu/legalcontent.

Sokolov Ya.V. (2004). Ocherki razvitiya audita [Essays on the development of audit]. Moscow : ID FBKPRESS, 376 pages.

The Law of Ukraine "On Audit of Financial Reporting and Audit Activity" № 2258-VIII of 21.12.2017. Retrieved from http:// www.zakon.rada.gov.ua/go/2258-19 [in Ukrainian].

Uilyamson O. (1996). Ekonomicheskie institutyi kapitalizma. Firmyi, ryinki, «otnoshencheskaya» kontraktatsiya [The economic institutions of capitalism. Firms, markets, "relative" contracting]. SPb. : Lenizdat, 476 pages.

Veblen T. (1984). Teoriya prazdnogo klassa : ekonomicheskoe issledovanie ob institutah [The theory of the idle class: an economic study of the institutes]. Moscow: Progress, 368 pages. 